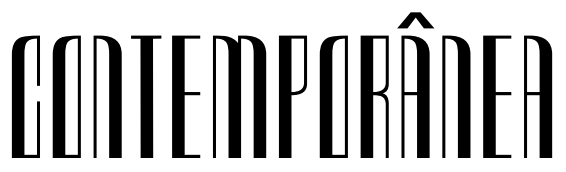
hitps://doi.org/10.31560/2316-1329.v10n3.10

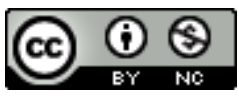

Contemporânea

Set-Dez. 2020

Esta obra está licenciado com uma Licença Creative Commons Atribuição-NãoComercial 4.0 Internacional.

Seção Especial: Diásporas africanas: enfoques e perspectivas

\section{Desafios à descolonização epistêmica: práticas, contextos e lutas para além das fraturas abissais}

Maria Paula Meneses'

Resumo: No início do século 21, os múltiplos processos diaspóricos que moldaram a história do nosso mundo expressam várias relações de violência ontológica e epistêmica. Essas relações, que combinam a emergência da alteridade com a inferioridade, estão na base da relação poder-saber entre os saberes, no cerne das modernas estruturas colonial-capitalistas. Essa relação opera pela imposição permanente de um pensamento abissal caracterizado por uma profunda cisão epistêmica e ontológica. Assumindo o conceito de diáspora como elástico e inclusivo é difícil comparar e traduzir entre várias realidades e experiências diaspóricas e não diaspóricas. Este artigo, inspirado nas Epistemologias do Sul, busca, por um lado, traçar uma cartografia analítica das experiências de lutas contra as condições de opressão que moldam nossos tempos, abordando questões de poder, economia, política e cultura e como esses elementos continuam a reproduzir a relação colonial-capitalista. Por outro lado, partindo do pressuposto de que a diversidade epistemológica do mundo é infinita, procura criar condições para reconhecer, de forma mais profunda, a diversidade de saberes ancorados nas experiências de luta de grupos sociais que viveram múltiplas e sistemáticas situações de injustiça, opressão e destruição. Esta abordagem visa contribuir para a descolonização do conhecimento, debatendo de forma construtiva as

1 CES - Centro de Estudos Sociais da Universidade de Coimbra - Coimbra - Portugal - menesesp@fe.uc.pt 
experiências promovidas por uma diversidade de comunidades diaspóricas e não diaspóricas, aprofundando os diálogos no Sul global, condição para transformações sociais e políticas para além do colonial-capitalista pensamento abissal. Palavras-chave: epistemologias do Sul; colonialismo; capitalismo; colonialidade; linha abissal.

\section{Challenges to epistemic decolonization: practices, contexts and struggles beyond abyssal fractures}

Abstract: At the beginning of the 21st century, multiple diasporic processes that shaped the history of our world express various relationships of ontological and epistemic violence. These relationships, which combine the emergence of alterity with inferiority, underlies the power-knowledge relationship among knowledges, at the core of the modern colonial-capitalist structures. This relationship operates through the permanent imposition of an abyssal thought characterized by a deep epistemic and ontological rift. Assuming the concept of diaspora as elastic and inclusive, it is difficult to compare and translate between various diasporic and non-diasporic realities and experiences. This article, inspired by the Epistemologies of the South, seeks, on the one hand, to draw an analytical cartography of the experiences of struggles against the conditions of oppression that shape our times, addressing issues of power, economics, politics and culture and how these elements continue to reproduce the colonial relationship-capitalist. On the other hand, assuming that the epistemological diversity of the world is infinite, it seeks to create conditions to recognize, in a deeper way, the diversity of knowledges anchored in the experiences of struggle of social groups that have experienced multiple and systematic situations of injustice, oppression and the destruction. This approach aims to contribute towards the decolonization of knowledge, debating in a constructive way the experiences advanced by a diversity of diasporic and non-diasporic communities, deepening the dialogues in the global South, a condition for social and political transformations beyond the colonial-capitalist abyssal thinking.

Keywords: epistemologies of the South; colonialism; capitalism; coloniality; abyssal line.

\section{Introduç̃̃o}

A ligação entre os desafios colocados pelo Sul global aos estudos em torno das diásporas é fundamental, embora nem sempre óbvia. Em causa está o 
reconhecer da diversidade social do mundo, espelho da diversidade de contribuições ao conhecimento-mundo. Este artigo procura contribuir para este debate acadêmico, identificando algumas das formas de abordagem dos saberes do Sul. Este percurso analítico entre os estudos do Sul global e diaspóricos convida a examinar a singularidade de cada contexto, ao mesmo tempo que considera as contribuições e ligações entre pessoas e lugares. Longe de esgotar a questão, este artigo tem por objetivo considerar a complexidade do tema e o seu contributo analítico, fundamental para um alargar e consolidar a tradutibilidade intercultural entre os saberes e experiências que compõem o Sul global (Fabian, 2014; Santos, 2018). Esta proposta reclama o reconhecimento dos seres (existência) e dos seus saberes e experiências parte de um mundo amplo, cujas contribuições são fundamentais a um saber universal que não é universalizável (Diagne, 2013: 07-08).

Qualquer leitura, independentemente da sua origem, ao privilegiar uma análise monocultural e hierarquizada da diversidade do mundo, reproduz uma lógica exclusivista. Uma das características da modernidade nortecêntrica consiste na criação e reforço permanente de uma hierarquia intelectual, na qual as tradições culturais e intelectuais do Norte global são impostas como o cânone, autodefinidas como superiores porque mais desenvolvidas (Trouillot, 2002: 220). A consequente periferização do "resto do mundo" é fruto de um projeto geopolítico ainda profundamente marcado pelo colonialismo, que insiste em (re)produzir como epicentro da relação ser-saber os contextos do Atlântico Norte, espaço gerador de referenciais universais legítimos (Meneses, 2018). Este projeto racional, nortecêntrico, vai criar a alteridade como um espaço/ tempo anterior, em que circulavam saberes considerados "inferiores". Este foi o contraponto que legitimou a imposição violenta da estruturação hierárquica que está na base da relação de poder-saber do moderno pensamento científico. Esta relação opera por meio da permanente imposição de um pensamento abissal que divide o mundo em duas partes: o mundo moderno nortecêntrico, de um lado, e o "outro" lado da linha, cuja diversidade tende a ser apresentada de forma uniforme como espaços cujos saberes detêm um valor meramente local, espaço da tradição, para serem substituídos pelo saber científico moderno (Santos, 2007: 46-47). ${ }^{2}$ Neste contexto, o Sul global refere-se metaforicamente às epistemologias que foram silenciadas, localizadas ou destruídas, fruto da

2 Nesta sequência, os 'outros' sistemas de saber são apresentados como expressões culturais anteriores e menos sofisticadas, reflexo de uma posição de força do saber científico que, longe de ser democrática, tem vindo a silenciar ou secundarizar saberes produzidos e usados pelos povos do mundo no seu quotidiano. 
relação violenta, do capitalismo, colonialismo e patriarcado sobre "a alteridade" (Santos, 2014; 2018). ${ }^{3}$

Vários são os processos diaspóricos que compõem a história do mundo, fruto das relações de violência ontológica e epistêmica, que conjugam a criação de situações de alteridade com as de inferiorização. Nesse sentido, e como Edward Alpers (1997) destaca, a noção de diáspora é bastante elástica e abrangente, condição que, ao garantir-lhe utilidade funcional, gera também situações de imprecisão analítica, dificultando a comparação e a tradutibilidade entre várias realidades e experiências (Santos, 2018). Tratando dos saberes associados a grupos cuja existência tem sido sistematicamente subalternizada e silenciada, as Epistemologias do Sul representam "um tempo de imaginação epistemológica que visa refundar a imaginação política [...] e fortalecer as lutas sociais contra a dominação" (Santos, 2018: 126-127). Ao "ocuparem" o conceito convencional de epistemologia, as Epistemologias do Sul apropriam-se dele para incentivar a produção e a validação de conhecimentos ancorados nas experiências de resistência e de luta dos grupos sociais que experimentam sistematicamente a injustiça, a opressão e a destruição, consolidando o conhecimento do mundo a partir de diálogos entre a partes potencialmente infinitas que compõem o universo.

As origens de muitos dos processos diaspóricos que hoje conhecemos estão associadas a processos de dispersão forçada, levando a que haja múltiplas utilizações políticas da noção de diáspora. É disso exemplo a posição de Mary Kaldor (1996), que identifica a presença, quer de cosmopolitas antinacionalistas, quer de etnonacionalistas reacionários entre os grupos diaspóricos. Já para Homi Bhabha o espaço é interpretado como combinando vários saberes. Esta combinação híbrida espelha a essência de vários contextos diaspóricos, aquilo que este autor caracteriza como um terceiro espaço (Bhabha, 2004: 55). Na opinião de James Clifford, o conceito de diáspora deve integrar não só o estudo da translocalidade e movimento, mas também de lutas políticas que contribuem para definir o local como uma comunidade distinta, em contextos históricos de deslocamento (Clifford, 1994: 308). Esta análise sofisticada dos violentos processos de deslocamento, característicos de sociedades que vivenciaram regimes de dominação política, epistêmica e de desigualdade econômica, também produzem culturas de resistência. Estas resistências têm várias formas, incluindo a manutenção das cosmovisões, línguas e espiritualidades, expressões de

3 O Sul é, ele próprio, como localização geopolítica, um produto da relação colonial-capitalista e, por isso, a aprendizagem com o Sul exige igualmente a desfamiliarização em relação ao Sul imperial, o Sul que reproduz a relação colonial-capitalista. É por isso que o Sul global é, simultaneamente, uma proposta utópica ontológica, política e epistemológica (Santos, 2006: 33). 
desafio a qualquer saber externo que, embora não necessariamente violentas, representa(va)m uma ameaça a qualquer tentativa de dominação epistêmica, como este artigo procura analisar.

Com efeito, a possibilidade de descolonização epistêmica está intimamente associada à ideia de diálogo, muito além de qualquer tentativa de essencialismo estratégico em relação a qualquer grupo diaspórico fechado sobre si mesmo. É este encerramento e, em geral, do "resto" do mundo em relação ao Norte global, que importa questionar, pois é uma das mais fortes heranças de dominação e opressão epistemológica e ontológica. Este artigo, ao contribuir para uma cartografia da diversidade epistemológica do Sul global identifica várias contribuições de diásporas contemporâneas ao aprofundamento dos diálogos no Sul, condição para transformações sociais e políticas para além da relação colonial-capitalista.

\section{Da linha abissal racial à linha abissal epistemológica}

W.E.B. Du Bois expõe vivamente a violenta segregação racial da sociedade norte-americana: "um americano, um negro; duas almas, dois pensamentos, dois esforços inconciliáveis; dois ideais em guerra num só corpo escuro, cuja força tenaz apenas é o que o impede de se dilacerar"4 (1903: 03). Esta argumentação expressa como a exploração econômica capitalista contemporânea não é compreensível sem a emergência do outro como sujeito racializado, sub-humano. Este exercício de negação total da humanidade dos sujeitos que habitavam o "outro" lado da linha racial, revela uma fratura ontológica, que leva este autor a afirmar que "o problema do século XX é o problema da linha racial" (Du Bois, 1903: 19).

Subjacente à filosofia política das antigas metrópoles coloniais está a ideia de que as lutas de libertação anticolonial do século XX puseram fim ao colonialismo (Meneses, 2010; 2018). Todavia, o colonialismo não terminou, apenas se reconfigurou, o que dificulta nomear e caracterizar adequadamente este complexo processo de continuidade e mudança. As degradações ontológicas e epistemológicas associadas aos processos de conquista colonial transformam os territórios, em terra nullius, que se podiam ocupar, física e epistemicamente. E esta forma de dominação da modernidade colonial-capitalista está insidiosamente presente em diversos contextos globais. No séc. XXI, o pensamento abissal persiste, caracterizado por uma profunda fratura epistêmica e ontológica

4 As traduções são minhas neste texto. 
(Santos, 2018). A exclusão das realidades e experiências do outro lado da linha é tal que tudo o que elas revelam sobre o mundo da vida e da cultura é considerado sem valor ou com valor residual, local e contextual.

Analisando a realidade de vários países formados (e deformados) a partir do violento encontro colonial, vários intelectuais e políticos têm caracterizado a realidade social e experiência dos estados independentes configurando uma situação de "colonialismo interno", que perpetua as exclusões abissais. Nos "novos" países que emergem fruto da emancipação anticolonial o projeto político continua a ser o moderno Estado-nação. Nestes contextos, o nacionalismo é um princípio político que procura promover a semelhança cultural enquanto vínculo social básico (Gellner, 1995: 03). Neste sentido, e porque muitos dos modernos estados integram vários grupos culturais, a imposição de uma cultura como a hegemônica está na origem de situações de colonialismo interno. Refletindo sobre o caso mexicano, Pablo Gonzalez Casanova sublinhou que o "o colonialismo interno corresponde a uma estrutura de relações sociais baseadas na dominação e na exploração entre grupos distintos culturalmente heterogéneos" (1965: 33). Tais relações são fruto da permanência de estruturas de poder colonial nas sociedades que emergiram no século XIX das lutas de independência das antigas colônias americanas de Espanha. Alguns anos depois esta análise foi aprofundada por Rodolfo Stavenhagen. Em um México dominado politicamente pelos mestizos, os povos indígenas haviam perdido as suas terras, sendo obrigados a trabalhar para "estrangeiros", coagidos a entrar em uma economia monetária (1970: 271). Essas relações, resultado de uma conceção monocultural de desenvolvimento em um contexto marcado por profundo racismo e estratificação social rígida, legitimaram o uso dos indígenas como mão de obra barata e descartável.

Em relação aos EUA, William Tabb encontra uma forte semelhança entre, por um lado, as tensões econômicas que caracterizam a relação do gueto [negro] com a "América Branca" e, por outro, entre as nações do Terceiro Mundo e os países industrialmente avançados (1970: 15). A esta leitura juntou-se a questão dos chicanos, [também] vítimas do imperialismo americano tal como os seus irmãos empobrecidos na América Latina (Valdez e Rubalcava, 1972: 215). Por meio da proposta conceptual de colonialismo interno, a realidade vivida nos EUA expôs o privilégio racial dos brancos, particularmente na estrutura de

5 Em alguns trabalhos mais recentes, um termo similar usado é o de 'colonialismo doméstico', conceito usado para refletir sobre as situações de colonialismo/neocolonialismo no presente (Calderón-Zaks, 2010). 
mercados de trabalho em detrimento dos negros, chicanos e outras comunidades subalternas (Blauner, 1972).

A realidade experimentada na África do Sul do Apartheid pela maioria não-branca foi também analisada com base no conceito de colonialismo interno. A caracterização feita pelo partido comunista sul-africano sobre as lutas que atravessavam este país na década de 1960, em pleno Apartheid, revelava uma África do Sul independente, na qual a maioria do povo não desfrutava nem de independência nem de liberdade, com o poder político e econômico concentrado nas mãos de uma minoria branca. O partido concluía a sua análise afirmando que "a África do Sul não branca permanece colônia da própria África do Sul branca", que controla o poder político e econômico (1962: 26). Por sua vez, Kwame Nkrumah (1965), destacado líder nacionalista africano, propôs o conceito de neocolonialismo para caracterizar o domínio que as antigas potências coloniais continuavam a deter sobre as suas antigas colónias, agora países supostamente independentes. Como salientou, a essência do neocolonialismo é que o Estado que está sujeito a ele é, em teoria, independente e tem todas as aparências externas da soberania internacional. Na realidade, porém, o seu sistema econômico e, portanto, sua política, é dirigida de fora (Nkrumah, 1965: ix).

Se no século XX o tempo que medeia entre a Conferência de Bandung e a Conferência Tricontinental simboliza, à escala global, as independências políticas do Sul e o surgimento de novos sujeitos políticos, ${ }^{6}$ esta emergência política não se traduziu, de imediato, em uma emergência epistêmica. 0 legado da ideologia colonial fora tão pesado que nos antigos territórios coloniais os saberes dos seus habitantes continuaram a ser, frequentemente, subalternizados, contando como referentes locais, dotados de um valor particular, útil apenas no âmbito local.

Ao longo das últimas décadas, porém, o mundo tem vindo a conhecer uma viragem epistêmica. São várias as lutas que, em vários contextos do Sul, procuram conferir inteligibilidade e intencionalidade às múltiplas experiências sociais. Esta emergência está representada na diversidade de grupos de trabalho que, particularmente no domínio das ciências sociais e das humanidades, têm vindo a denunciar a violência gerada pela linha abissal epistemológica e procuram desenvolver instrumentos teóricos e analíticos, assentes nas suas experiências, que deem sentido às complexas transformações que caracterizam as

6 Este espaço-tempo tem conhecido múltiplas designações, várias das quais são exploradas neste volume: o Oriente, o Mundo Primitivo, o Mundo Colonial, o Terceiro Mundo, o Mundo subdesenvolvido, o Mundo em desenvolvimento e o Sul global. 
sociedades contemporâneas. O pensamento abissal, é, pois, uma das características marcantes dos desafios que as lutas no Sul global enfrentam.

As crises sociais, econômicas, financeiras e políticas que têm avassalado o mundo contemporâneo exprimem um sentimento de exaustão histórica e política do moderno projeto racional eurocêntrico, o Norte global (Santos, 2017).? Após vários séculos procurando "ensinar" o mundo, este projeto mostra-se incapaz de resolver os problemas que o mundo contemporâneo enfrenta (no qual se destacam a crise ambiental; a violação permanente de direitos humanos; as guerras irregulares, a degradação da democracia e as crises financeiras), (Santos, 2014). Contrastando com o esgotamento intelectual e político do Norte global, o Sul global, na sua imensa diversidade, assume-se hoje como um vasto campo de inovação social, cultural, política, econômica e epistêmica. Neste sentido, a denúncia do "outro" lado da linha abissal e a luta pela sua superação é o ponto de partida das epistemologias do Sul e suas propostas para repensar a diversidade epistêmica do mundo.

Neste contexto, é fundamental analisar algumas das principais linhas de resistência e teorização epistemológica desenvolvidas por ativistas e acadêmicos do Sul global. Neste artigo procuro, de forma sucinta, expor como outras ontologias e epistemologias - independentemente da sua posição geográfica - têm contribuído para tornar mais densa a paisagem das lutas emancipatórias no mundo. Procuro também mostrar como, em vários contextos, diferentes sociedades respondem umas às outras e às questões de descolonização e de luta contra a globalização neoliberal. O objetivo é valorizar e amplificar os saberes que resistiram com êxito à intervenção capitalista-colonial, ${ }^{8}$ investigando as condições de um debate dialógico tendencialmente horizontal entre estes conhecimentos, ou seja, as condições para uma ecologia de saberes (Santos, 2014;

7 Enquanto projeto epistêmico e geopolítico, o Norte global, desenvolve-se a partir da Europa, desde o séc. XV e, do séc. XVIII em diante, concede um privilégio absoluto à racionalidade científica moderna. Segundo Santos, a racionalidade moderna tem como principais premissas: (1) a ciência baseada na observação sistemática e na experimentação controlada é uma criação específica da modernidade de matriz eurocêntrica, radicalmente distinta de outros saberes oriundos de outras regiões e culturas do mundo; (2) o conhecimento científico, tendo em vista seu rigor e potencial instrumental, é radicalmente diferente de outras formas de conhecimento, sejam leigos, populares, práticos, de senso comum, intuitivos ou religiosos (Santos, 2018: 05). Este excepcionalismo é fundacional ao estabelecimento da linha abissal que separa o mundo metropolitano, do Norte, das sociedades e sociabilidades que ocupam os 'espaços coloniais', o Sul global.

8 Neste artigo, procurei não tratar conceitos como raça, etnia, gênero e classe como reflexões independentes. Pelo contrário, estas categorias são tratadas como características que se sobrepõem, que estão inextricavelmente interligadas, e que se intersectam na forma como criam e sustentam sistemas de desigualdade e opressão a nível global. 
2018). Estas epistemologias, ancoradas em contextos históricos e sociais específicos, mostram a vinculação recíproca entre formas de conhecer, de existir e de resistir. A esperança é encorajar um debate construtivo e dialógico sobre os complexos laços que unem o Sul, contribuindo para ajudar a imaginar e criar uma cultura cosmopolita subalterna, mais democrática, igualitária e solidária.

\section{0 fim do colonialismo? Desafios à descolonização ontológica e epistêmica}

A luta pela descolonização é um dos elementos fundacionais do século XX. A descolonização inclui a análise de lutas, de compromissos, de acordos e de resultados, o repensar dos aspetos fundamentais de quem tem o poder e de quem o contesta. Para Fanon, o horizonte final da descolonização representa a construção de uma nova humanidade capaz de escapar da lógica da interminável repetição da destruição de saberes nos espaços coloniais (1961). Para Nkrumah, a descolonização sintetiza a criação de uma humanidade política e economicamente autônoma (1965). Para Gandhi e Sukarno, a descolonização é a possibilidade de decidir o presente e o futuro por meio das condições e possibilidades e saberes existentes (Sukarno, 1955; Gandhi, 1956).

Os desafios à descolonização do pensamento (Alatas, 1974; Thiongo, 1993) têm assumido formas diversas, marcadas pela especificidade da articulação entre capitalismo e colonialismo, em diferentes regiões e em diferentes momentos históricos. ${ }^{9}$ Para Santos (2018), a descolonização significa a luta por um mundo pós-abissal, um mundo que elimine as exclusões abissais, aquelas que implicam a degradação ontológica e epistêmica dos grupos excluídos. A inevitabilidade do processo de descolonização está associada à libertação do "regime da verdade" disseminado por meio do projeto colonial, o que inclui, entre outros aspetos, como Fanon (1952) sublinha, a dissolução do complexo de inferioridade e da alienação dos colonizados.

Considerando a realidade latino-americana, Aníbal Quijano (1991) expôs a continuação da herança política colonial após o fim do colonialismo histórico, por meio do conceito de "colonialidade", que se tornou a pedra angular do projeto descolonial. Limitar a análise do colonialismo a uma única variante, - ao colonialismo histórico, de ocupação efetiva territorial por poderes estrangeiros - deixa de fora as metamorfoses que o colonialismo tem conhecido, incluindo

9 Importa ter em atenção a distinção entre diferença e diversidade. Para Gilles Deleuze, a "diferença não é diversidade. A diversidade é dada, mas diferença é aquela pela qual o dado é dado, pela qual o dado é dado como diverso" (1994: 222). Ou seja, em linha com este autor, a diferença é uma condição geral, preexistente à diversidade, e que permite que os fenômenos sejam percebidos como diversos. 
as tentativas de retorno do projeto colonial..$^{10}$ Insistir em uma leitura histórica linear não dá conta destas continuidades, pelo que importa caracterizar as várias formas que o colonialismo e a descolonização vêm assumindo ao longo dos últimos séculos.

O conceito de "viragem descolonial", avançado por Nelson Maldonado-Torres (2007: 160), ambiciona mostrar como a descolonização do pensamento eurocêntrico ou, mais precisamente, das ciências sociais é um fenômeno multissituado e com raízes antigas. Na verdade, a ideia de descolonização sempre acompanhou o pensamento dominante como um fluxo subalterno ou marginal. É claro que esta ideia nem sempre foi identificada pelo termo "descolonização", mesmo que o seu objetivo fosse questionar a legitimidade do empreendimento colonial.

\section{A descolonização no contexto (pan)africano}

O conceito de Negritude é fruto de um grupo diaspórico integrando, na França, intelectuais antilhanos e africanos (Diagne, 2018). O surgimento da negritude nos círculos literários em Paris representou um espaço político de lutas identitárias, a expressão de uma revolta contra a situação histórica do colonialismo e racismo do império francês. Negritude, uma demanda política e cultural, correspondia à recusa da dominação colonial, do domínio pela conquista, escravidão, deportação, negação cultural e espiritual, opressão política e exploração econômica - negação e opressão legitimadas pela suposta superioridade da raça branca e a excelência da civilização europeia (Meneses, 2016). Tal desafio intelectual gerou um programa político radical capaz de promover a descolonização no contexto da época, lidando com questões tão diversas quanto a assimilação, a crioulização, a racialização e o colonialismo.

O mundo pós-II Guerra Mundial tinha nos EUA e na Europa ocidental os principais apoios da construção da visão da ONU sobre o mundo. Césaire e Senghor, expoentes intelectuais da Negritude, ambicionavam algo diferente, desafiando os próprios princípios da territorialidade, nacionalidade e soberania do Estado. Unia-os o desejo utópico de acabar com o colonialismo sem cair no que cada um considerava ser a armadilha de uma independência nacional sem agência política. Na visão de Senghor, "a independência cultural é a pré-condição necessária a todas as outras formas de independência: política, econômica, social" (Senghor, 1971: 285). Dando eco a esta perspetiva política, Césaire e Senghor propuseram, em alternativa, uma estrutura legal e política

10 Veja-se, a este respeito, os debates suscitados na sequência da publicação do artigo de Gilley (2017). 
que reconhecesse uma narrativa histórica interligada que unia os povos metropolitanos e ultramarinos entre si. Esta proposta política pós-abissal almejava, por um lado, proteger as reivindicações econômicas e políticas dos povos das Caraíbas e de África em relação a França, uma sociedade cuja riqueza haviam ajudado a criar; por outro lado propunha-se reforçar, de forma horizontal, a interdependência entre a metrópole e as antigas colônias. Este projeto utópico esteve na origem da luta constitucional fracassada que procurou transformar o império francês em uma federação transcontinental, democrática e socialista. No cerne desta proposta política utópica pós-abissal estava a possibilidade de reinvenção de uma forma política para a ordem mundial, uma nova forma pós-nacional de democracia, um projeto político utópico para o Sul e a partir do Sul (Wilder, 2015). Em vez de exigir a descolonização da Martinica ou do Senegal, pediam aos caribenhos e aos africanos para descolonizarem a França. Tal projeto de associação de povos autogovernados não conheceu apoios e caiu no esquecimento.

Abordando a descolonização tendo em vista o prisma epistêmico, Wa Thiongo (1993) assumiu a proposta de Césaire-Senghor como uma promessa libertadora, um encontro que facilitaria a autocompreensão após séculos de submissão, desmembramento e alienação. O conceito de "desmembramento" capta não apenas a fragmentação física, mas também a colonização epistemológica da mente, bem como a "decapitação cultural" que resultou em formas profundas de alienação entre os africanos. Como este autor salienta:

O desmembramento da África acontece em duas etapas. Durante a primeira, o africano é dividido em duas metades: o continente e a sua diáspora. [...] Se aceitarmos que o comércio de escravos e a escravidão nas plantações proporcionaram a acumulação primária de capital que tornou possível a Revolução Industrial da Europa, não podemos fugir do fato que as exigências da Revolução Industrial - mercados para produtos acabados, fontes de matérias-primas, e a defesa estratégicos das rotas comerciais - levou à segunda etapa de desmembramento do continente [...]. Tal como as plantações de escravos pertenciam a várias potências europeias, a África pós-Conferência de Berlim foi transformada em uma série de plantações coloniais pertencentes a muitas das mesmas potências europeias (Thiongo, 2009: 05-06).

Por sua vez, Kwasi Wiredu defende uma descolonização conceitual da filosofia africana partindo das interferências e contactos havidos, num desafio a qualquer projeto filosófico primordial: 
Por descolonização refiro-me ao desinvestir do pensamento filosófico africano de todas as influências que emanam de nosso passado colonial [...]. Obviamente, não será racional rejeitar tudo que tiver ascendência colonial. Concebivelmente, um pensamento ou um modo de investigação produzido pelos nossos ex-colonizadores pode ser válido ou, de alguma forma, benéfico para a humanidade. Estamos a apelar à sua rejeição ou à ignorância da sua existência? Tal atitude seria uma loucura (Wiredu, 1998: 17).

Paulin Hountondji, cuja trajetória intelectual é um exemplo eloquente das complexas relações entre o conhecimento eurocêntrico e o afrocêntrico, critica a extroversão dos produtores de conhecimento na periferia e sua dependência em relação às fontes externas de autoridade. Este filósofo propõe o conceito de conhecimento endógeno, que combina a ideia da produção ativa e autônoma de conhecimento pelas sociedades africanas com a ideia da sua disseminação e relevância, mais além do contexto em que a produção ocorre: para o Continente Negro a equidade requer que todo o conhecimento acumulado ao longo dos séculos e versando sobre diferentes aspectos de vida seja compartilhado por todas as pessoas que vivem no continente. Exige que sejam tomadas medidas adequadas para facilitar uma apropriação lúcida e responsável, por parte de África, do conhecimento disponível, e das discussões e interrogações desenvolvidas em outros lugares. Essa apropriação deve ir a par com a reapropriação dos próprios conhecimentos endógenos de África e, além disso, assumir uma apropriação crítica do próprio processo de produção de conhecimento e de capitalização (Hountondji, 2009: 09-10).

É neste sentido que Hountondji assume a descolonização como a desmarginalização do continente, um exercício que define como, simultaneamente epistêmico e ontológico, questionando as heranças do poder colonial (1997). Aprofundando esta linha de pensamento e ação, Achille Mbembe caracteriza brilhantemente o exercício do poder político em África após as independências, propondo o conceito de "pós-colônia", um novo tipo de colonialismo, que acontece depois do final do colonialismo histórico:

A pós-colônia é caoticamente pluralista, ainda que, no entanto, tenha uma coerência interna. É um sistema específico de signos, um modo particular de fabricar simulacros ou reformar estereótipos. Não é, porém, apenas uma economia de signos em que o poder é espelhado e imaginado de forma autorreflexiva. A pós-colônia é caracterizada por formas [de poder] distintas através das quais as identidades são multiplicadas, transformadas e postas em circulação (Mbembe, 1992: 03-04). 
O palimpsesto de estruturas de poder resultante da sobreposição de várias culturas políticas e jurídicas caracteriza muitas realidades pós-coloniais contemporâneas. Como Mbembe enfatiza, o peso dos legados coloniais resulta em uma situação de "necropolítica", descrita pelo autor como um exercício de poder visando principalmente "a instrumentalização generalizada da existência humana e a destruição material de corpos e populações humanas" (2003: 14). Para Santos, a necropolítica corresponde à persistente desumanização de vastos grupos populacionais, refletindo a persistência do pensamento político abissal $(2014,2018)$. Situadas do outro lado da linha, estas populações representam espaços de exceção, espaços habitados por sub-humanos, sem saberes, sem direito a existir.

As perspectivas críticas desde alguns grupos asiáticos

No contexto asiático, as lutas pela descolonização conheceram múltiplas manifestações. Uma das mais conhecidas é o Grupo dos Estudos Subalternos, criado na Índia na década de 1970 sob a orientação de Ranajit Guha (1982). O principal objetivo deste grupo centrou-se na análise crítica não apenas da historiografia colonial indiana empreendida pelos europeus, mas também da historiografia nacionalista indiana eurocêntrica, e da historiografia marxista ortodoxa.

Para os membros deste grupo, a história do nacionalismo indiano revelava-se uma história das conquistas realizadas por elites, fossem elas indianas ou britânicas. Nesta narrativa não havia espaço para as contribuições de pessoas individuais ou coletivas para a criação e desenvolvimento do nacionalismo (Guha, 1982: 03). Desafiando esta posição, os estudos subalternos refletem a tentativa de alinhar o raciocínio histórico com movimentos mais amplos que lutaram e lutam pela democracia na Índia. A leitura crítica do colonialismo moderno realizada por este grupo apresenta-nos a relação indissociável entre o capitalismo e o colonialismo, uma relação histórica que associa um capital expansionista, e cada vez mais global, a sociedades não-eurocêntricas, relação que ocorre sem afetar ou exigir qualquer transformação democrática profunda nas relações sociais de poder e autoridade. Recorrendo a Gramsci, por meio do seu conceito neo-marxista de "subalterno", o objetivo expresso deste grupo foi produzir análises históricas em que os grupos, cujas experiências e opiniões não eram tidas em atenção, fossem agora compreendidos como sujeitos da história. E estes sujeitos entravam na história como expressões de resistência à dominação das elites locais. 
Em um desafio aberto a uma leitura linear e determinista da história, os estudos produzidos mostraram a participação ativa dos camponeses, de grupos tribais e de outros grupos diaspóricos com uma "consciência subalterna” anti-hegemônica na construção da moderna política da Índia, primeiro como ativistas no movimento nacionalista, durante a época colonial e depois como geradores da democracia indiana. Estes estudos identificaram nestas lutas, expressões de um sistema insurgente de valores não-elitistas, que haviam sido caracterizados em estudos anteriores quer como momentos de desordem ou mesmo como ações criminosas (Guha, 1999). Como vários dos membros deste grupo advogaram, caracterizar as ações das classes subalternas na Índia colonial como "pré-políticas" equivalia a repetir um historicismo elitista.

A separação entre a elite e o domínio político dos subalternos teve implicações radicais para a teoria social, incluindo a separação relativa da história do poder das histórias universalistas do capital; uma crítica sofisticada da relação de poder no projeto do estado-nação, e, finalmente, uma interrogação da relação entre poder e conhecimento (Chakrabarthy, 2003: 195). Para Edward Said (1988: v) estas reflexões intelectuais sobre o exercício da história e o espaço geopolítico da Índia tiveram um efeito insurrecional, intelectualmente importante. Apesar das críticas feitas a este grupo (por exemplo, a ausência de uma reflexão feminista e a pouca atenção dada à questão muçulmana e mesmo ao papel da espiritualidade na Índia), as suas reflexões têm contribuído para uma alteração radical da leitura quer das antigas sociedades coloniais, quer da história da Europa, elementos fundamentais para a construção social do conhecimento desde o Sul e com o Sul.

Mais recentemente, por exemplo, um dos membros dos Estudos Subalternos indianos, Shahid Amin propôs uma importante revisão histórica sobre o recente ressurgimento da divisão entre o Indiano - hindu e o Paquistanês-muçulmano e explorou as possibilidades e os limites da ideia de pluralidade e diversidade (Amin, 2016). Em um outro patamar, igualmente alinhadas com esta tradição crítica, as reflexões de Sujata Patel (2014) sobre o surgimento de uma escola de ciências sociais indianas, estudando a trajetória de vários cientistas indianos, permitiu caracterizar a construção de teorias alternativas da modernidade fundamentadas em uma imaginação sociológica nacionalista e anticolonial.

Igualmente em contexto asiático, outra linha de pensamento descolonizador tem vindo a ser desenvolvida por Syed Alatas. Alatas denuncia o peso do legado colonial na educação contemporânea, um legado que produz uma "mente 
acrítica e imitativa, dominada por uma fonte externa, cujo pensamento torna impossível qualquer perspectiva independente" (1974: 692). Com base em um profundo conhecimento das ciências sociais eurocêntricas, Alatas expõe as suas insuficiências para uma compreensão adequada das sociedades não ocidentais; ao mesmo tempo, enfatiza a riqueza do conhecimento islâmico, particularmente o conhecimento produzido nas regiões sul e sudoeste da Ásia. Juntamente com outros estudiosos, Alatas tem vindo a desenvolver um projeto sociológico (epistêmico e ético) que procura, por um lado, expor as bases coloniais do pensamento social europeu e, em paralelo, recuperar epistemologias não-ocidentais (Alatas, 2006: 786-787). Em uma vertente diferente, embora convergente, convém referir os trabalhos pioneiros de Ali Shariati (1979) que também defendeu a construção de uma sociologia islâmica. A análise do papel e da função da religião no contexto do Irã foi uma importante contribuição para pensar na separação entre a religião e a esfera política pública. Usando interpretações marxistas como o determinismo histórico e a luta de classes, Shariati procurou reinterpretar a teologia islâmica, dissociando os leigos radicais do clero tradicional e associando-se à trindade secular da revolução social, inovação tecnológica e autoafirmação cultural.

\section{0 grupo modernidade colonialidade}

A América Latina tem uma longa tradição de pensamento anticolonial e pós-colonial, na qual se destacam autores como José Carlos Mariátegui (2009), Paulo Freire (1970), Orlando Fals Borda (1970), Rudolfo Stavenhagen (1970), Pablo González Casanova (1965), Aníbal Quijano (1991, 2005), Enrique Dussel (1993, 2002), entre muitos outros Os dois últimos são hoje mais conhecidos por seu papel na formação do importante programa de pesquisa denominado Grupo Modernidade/Colonialidade. Um dos intelectuais de referência deste grupo, Walter Mignolo, expõe o desafio experimentado pelo grupo, ao procurar pensar o mundo desde um pensamento de fronteira: ${ }^{11}$

Porque o ponto de origem da descolonialidade era o Terceiro Mundo, tendo em atenção a diversidade de histórias locais e de tempos diferentes, e países imperiais ocidentais que primeiro interferiram com essas histórias locais [...] o pensamento de fronteira é a singularidade epistêmica de qualquer projeto descolonial (2013: 131).

11 Teorizar a partir da fronteira pode ser visto como um retorno sub-reptício ao projeto filosófico que define o "centro" e a "periferia". 
Outro conceito crucial é o de "transmodernidade", desenvolvido por Dussel, um projeto que deseja ir além da modernidade eurocêntrica, pois que, como este autor destaca, importa recuperar e (re)conhecer os saberes que o Ocidente nunca adotou, e ao contrário, desprezou e valorizou como "nada". Segundo ele, este espaço de (re)conhecimento terá uma função criativa de grande significado no século XXI (Dussel, 2002: 221). Por sua vez, Catherine Walsh, uma autora descolonial de referência, enfatiza a existência de uma longa tradição de pensamento crítico indígena e negro que raramente é reconhecido pelos acadêmicos e intelectuais de esquerda latino-americanos. Ao traçar os caminhos pelos quais os povos indígenas andinos e afrodescendentes mudaram a "geopolítica do conhecimento" (Walsh, 2009), esta autora traz aos presentes projetos epistêmicos e ontológicos há muito subalternizados.

Igualmente importante é o conceito de "colonialidade do ser", desenvolvido por Maldonado-Torres $(2007,2009)$, que expõe em detalhe como a privação ontológica ocorre por meio da raça, inscrição fatal que reafirma a linha abissal:

Se a colonialidade do poder se refere à inter-relação entre formas modernas de exploração e dominação e a colonialidade do saber está relacionado ao rol da epistemologia e às tarefas gerais da produção do conhecimento na reprodução de regime de pensamento coloniais, a colonialidade do ser refere-se, então, à experiência vivida da colonização e ao seu impacto na linguagem (Maldonado-Torres, 2007: 242).

No contexto da "Europa Decolonial", Ramón Grosfoguel tem avançado com uma perspectiva descolonizadora que articula o islamismo e o feminismo. Segundo ele:

a identidade religiosa muçulmana constitui hoje um dos mais proeminentes marcadores de superioridade/inferioridade ao longo da linha do humano. Os muçulmanos são hoje construídos na América do Norte e na Europa como 'bárbaros, 'atrasados', 'incivilizados', 'violentos', 'terroristas', abusivos de crianças, mulheres e gays/lésbicas, 'não adaptáveis aos valores europeus' etc. Eu digo 'um dos marcadores mais proeminentes' porque nestas duas regiões do mundo o racismo de cor continua a ser extremamente importante e enreda-se de formas complexas com o racismo religioso (Grosfoguel, 2016: 11).

\section{A Associação de Filosofia Caribenha}

Sylvia Wynter (2003), uma autora de referência nos estudos do Caribe denuncia a ontologia racista subjacente ao moderno projeto eurocêntrico, tema 
que tem sido trabalhado criticamente na Associação de Filosofia Caribenha. Esta associação tem desempenhado um papel crucial na promoção da revisão descolonizadora das diferentes tradições filosóficas e das ciências sociais por meio das lentes da crioulização.

A busca do "ser" é um elemento fundamental desta proposta, intimamente associada à busca da identidade do Caribe, na relação com os "outros". Se na origem das lutas políticas e ontológicas caribenhas esteve o conceito de negritude, a noção de "crioulidade", mais recente, desvia o olhar da África (memória da diáspora) e da Europa (memória colonial) para uma "outra América", ancorando o projeto epistêmico das identidades do Caribe. Como sublinhou Édouard Glissant (1989), compreender a especificidade das Caraíbas exige ultrapassar as identidades fixas, assentes nas antigas divisões raciais e nacionais; compreender os processos identitários de forma dinâmica e relacional abre caminho para se ultrapassar a dialética colonizador-colonizado, uma proposta que se aproxima do terceiro espaço de Bhabha (2004), já referido anteriormente.

Lewis Gordon (2000; 2015), trabalhando os legados de DuBois, C. L. R. James, Frantz Fanon, entre outros, procura promover o legado emancipatório presente nas "perspetivas desenvolvidas de baixo", atravessadas por experiências diaspóricas. Nos seus escritos, Gordon mostra como a invisibilidade, a ausência, o deslocamento, são atos constitutivos pelos quais a consciência do ego branco reconstrói o significado da existência negra. Esta invisibilidade não é apenas um ato físico; é também fundamentalmente um ato fenomenológico, isto é, uma ausência que se constitui como um significado na consciência branca. É na luta pela reconstituição do "eu" negro racializado, na esteira do desaparecimento fenomenológico de sua herança africana que assenta a identidade da filosofia caribenha.

O desafio de (re)pensar o mundo ecumenicamente, segundo uma proposta sincrética, é partilhado por Susan Buck-Morss. Como esta autora sublinha, uma perspectiva histórica alternativa comum está em emergência.

[É] nas descontinuidades da história que as pessoas, cuja cultura foi estendida até o ponto de ruptura, expressam uma humanidade que vai além dos limites culturais. E é na nossa identificação empática com esse estado cru, livre e vulnerável que temos uma oportunidade de entender o que eles dizem. A humanidade comum existe apesar da cultura e suas diferenças (2009: 133).

Neste contexto, Jane Gordon destaca o potencial emancipador da filosofia crioula, uma proposta que "se concentra em fins coletivos além daqueles da 
coexistência e tolerância básicas, [e que nos alerta] para a transformação mútua envolvida na moldagem daquilo que emerge como politicamente compartilhado" (Gordon, 2014: 03).

Em um mundo composto de um mosaico de saberes, o reconhecimento desta diversidade pode fornecer propostas de outras estruturas políticas, discursos, formas de identificação e pensamento, úteis ao progresso do Sul. Quando o universalismo eurocêntrico já esgotou as suas propostas teóricas, a crioulização, na proposta de Jane Gordon facilita a busca de conceitos e aspirações por meio do que Santos designa como ecologia de saberes. Indo além do diálogo de diferença, a crioulização explora a criação de novas constelações políticas e epistemológicas por meio dos relatos fragmentados de espaços políticos, físicos e geopolíticos compartilhados (Gordon, 2014: 163). A crioulização destas experiências e saberes gerados por contatos de diásporas abre as possibilidades a uma abordagem mais rigorosa das propostas políticas e ontológicas desde o Sul, num diálogo potencializador de ecologia de saberes.

\section{Sul global no norte geográfico}

Assumir o colonialismo como realidade do passado, ou exclusiva dos países geograficamente situados a Sul restringe a análise crítica do contributo das suas experiências, das resistências, e das posições políticas e epistemológicas que vêm desenvolvendo. Reconhecendo a diversidade das reflexões que procuram desmantelar a tripla estrutura de opressão que caracteriza os nossos tempos colonialismo, capitalismo e patriarcado - apresentamos alguns grupos exemplo de emergências epistêmicas e ontológicas no Norte geográfico.

O Parti des Indigènes de la République (PIR) é exemplo de um protesto atuante pelo reconhecimento, em contexto do Norte, de outras formas de ser e saber, que permanecem subalternizadas. Constituído em 2005, este movimento, integrando ativistas migrantes e descendentes de migrantes em França, luta contra todas as formas de dominação imperial, colonial e sionista à escala global.

Este movimento político tem vindo a denunciar a permanente discriminação de que são alvo os migrantes do norte da África (e seus descendentes) dentro da França, declarando inequivocamente que esta discriminação racial revela como este país permanece um estado colonial (Khiari, 2006). Neste contexto, o PIR ocupa radicalmente o conceito colonial indigène (indígena, nativo) como identidade política, um alerta para a fratura abissal que atravessa a França.

O PIR apela a uma descolonização da república francesa, apoiando-se, nesta luta, em ligações transnacionais solidárias que mantém com outros grupos 
marginalizados, dentro e fora da Europa. O grupo tem vindo a construir o seu projeto político com suporte de autores de referência do Sul global, com forte influência do grupo decolonial, já previamente mencionado. Como sublinham na sua página on-line, ${ }^{12}$ assumem uma identidade política de oposição ("anticolonialismo pós-colonial” - Robine, 2006: 135), opção política que permite denunciar a estrutura racial da sociedade francesa, ou seja, as novas formas de discriminação étnica inventadas para combinar a sensibilidade liberal com o projeto global de hierarquização racial que se mantém do passado colonial-capitalista (Khiari, 2006). Para estes intelectuais-militantes, ultrapassar o pensamento abissal é fundamental para ampliar a discussão sobre a França a partir das memórias coloniais de dominação e opressão até hoje reprimidas, (Bouteldja e Khiari, 2012).

A ficção histórica dominante insiste em associar o Mediterrâneo à Europa, identificando-o como o berço e centro das raízes históricas europeias e, em paralelo, do pensamento moderno. Esta interpretação de cariz universalizante está vindo a ser problematizada por meio de interpretações críticas que mostram a persistência de situações coloniais nesta região, marcada por séculos de epistemicídios. Neste contexto, a situação dos "migrantes" tem sido vista como o retorno da "situação colonial": por um lado aos refugiados e dos migrantes indocumentados que procuram chegar à Europa é-lhes frequentemente negada a sua humanidade; por outro lado, e tal como o PIR sublinha, os imigrantes de segunda e terceira geração são exemplo de "suis" coloniais nos países onde vivem, confrontados com situações de extrema violência e não reconhecidos como cidadãos com plenitude de direitos. Estas práticas desumanas vem sendo denunciadas por organizações, movimentos e intelectuais que reclamam uma "outra” forma de ser e estar no Mediterrâneo como zona de contato entre culturas milenares (Chambers, 2008; Gimeno e Castaño, 2016).

O conceito de colonialismo interno, já debatido antecedentemente, tem sido utilizado em tempos mais recentes também noutros contextos do Norte, como os EUA. Aqui, vários autores têm vindo a denunciar as análises sociológicas dominantes, que atenuam ou mesmo ignoram as dinâmicas históricas que explicam a manutenção de situações coloniais-capitalista nas sociedades do Norte. Para Ramón Gutiérrez, esta opção justifica-se porque:

O colonialismo interno oferece às minorias [afro-americanos e chicanos] uma explicação para a sua concentração territorial, segregação espacial,

12 Disponível em: <http://indigenes-republique.fr/>. Acesso em: jun. 2018. 
administração externa, para a disparidade entre a sua cidadania legal e a posição, de fato, de cidadãos de segunda classe, a sua brutalização pela polícia e os efeitos tóxicos do racismo nas suas vidas (2004: 282).

Entre as estratégias de colonialismo interno integram formas de segregação racial e desinvestimento nos projetos educativos para os grupos racializados (Edelman, 2007) ou a vigilância e criminalização, tanto estruturais quanto interpessoais (Harris, 2008). A manifestação das formas dominantes de opressão que caracteriza o nosso mundo - capitalismo e colonialismo entrosadas com o patriarcado - está expressa no facto de, em todas as áreas urbanas da Europa e dos Estados Unidos, um número desproporcional de mulheres prisioneiras ser oriunda de comunidades racialmente marginalizadas (Davis, 2002: 241).

Quer nos subúrbios negros pobres de Washington DC, quer entre os chicanos a leste de Los Angeles, estas denúncias expõem a presença colonial da linha abissal. A intelectual e ativista Angela Davis tem denunciado as injustiças que marcam o mundo contemporâneo, convidando-nos a imaginar e construir o horizonte da descolonização como um amplo movimento pela libertação da humanidade, um movimento que acontece também nos interstícios do Norte global. E ao fazê-lo, lembra-nos que "a liberdade é uma luta constante" (Davis, 2015).

\section{Os povos indígenas e os desafios epistemológicos}

Entre os povos indígenas, sobretudo de antigas colônias de povoamento, a permanência das relações coloniais é óbvia (Elkins; Pedersen, 2005). A "obrigação" do uso de línguas coloniais na educação (com as línguas indígenas a serem relegadas para uso local), a expropriação de fragmentos de saberes do mundo indígena, usados para construir a riqueza dos colonizadores (Tuck; Yang, 2012: 04) são referências explícitas do extrativismo dos saberes. A ocupação dos territórios, que transformou os povos originários em estrangeiros na sua própria terra, ilustra a íntima relação entre o capitalismo e o colonialismo. Na América do Norte, a apropriação de terras (por meio da criação de territórios indígenas) esteve mutuamente imbricada como a expansão do capitalismo: "o colonialismo de povoamento perpetua a aquisição de territórios" (Coulthard, 2014: 152, ênfase no original). O reconhecimento de "territórios indígenas" pelos estados modernos é interpretado por vários ativistas como a perpetuação da relação colonial-capitalista, reproduzindo as configurações do poder do Estado, as políticas coloniais, racistas e patriarcais. Descolonizar esta realidade é um desejo partilhado por povos que lutam pelo direito ao território como parte de uma exigência ampla de reconhecimento de direitos históricos. Da África do Sul à Finlândia, da Colômbia 
à Austrália, passando pelo Sahara e por toda a América Latina e central, são várias as conexões e solidariedades conjugadas na luta por um mundo pós-abissal. A análise crítica das tensões que condicionam a questão do direito à autodeterminação representa um importante momento de consolidação da luta, símbolo de um projeto global de descolonização (Tabar; Desai, 2017).

O genocídio e o epistemicídio são traços centrais da manutenção das políticas coloniais (Wolfe, 2006: 387), legitimadas por meio da gramática da racialização dos corpos e povos e grupos diaspóricos considerados inferiores. Vários intelectuais e ativistas têm denunciado esta pedagogia da impunidade do Norte global:

Para que os colonos façam da [colônia] o seu lugar, o seu lar, têm de destruir e fazer desaparecer os povos indígenas que lá vivem. Os povos indígenas são aqueles que têm histórias sobre a criação, e não histórias de colonização, sobre como eles chegaram a um lugar particular - de fato, como eles se tornaram esse lugar. $\mathrm{O}$ nosso relacionamento com a terra compreende as nossas epistemologias, ontologias e cosmologias. Para os colonos, os povos indígenas [são um entrave e...] através de leis e políticas, a terra é reformulada como propriedade, como um recurso. Ou seja, os povos indígenas devem ser apagados, devem ser transformados em fantasmas (Tuck; Yang, 2012: 06).

As lutas pelo reconhecimento de saberes indígenas, em contextos de colonização por povoamento, de que são exemplo os EUA, o Canadá ou a Austrália, revelam a íntima associação entre o colonialismo e o capitalismo, dando origem à continuidade destas opressões pela colonização interna (Connell, 2007; Santos, 2014). Nestes contextos, como propõem Tuck e Yang, a descolonização, por meio da devolução das terras, expressa o direito a outra história, à herança cultural destes povos, parte integral da herança da humanidade. A devolução é um projeto imenso, se se assumir a devolução da terra como reconhecimento da vida indígena como um contributo fundamental para riqueza comum da humanidade. Esta imensidão é o reconhecimento de que a descolonização exigirá uma mudança na ordem do mundo (Fanon, 1961). Exigirá uma ética distinta, de esperança e cuidado, que mais a Sul outros povos designam de corazonar (Santos, 2018: 99-102).

Alterar a natureza das narrativas coloniais passa pela descolonização da educação, com base em uma pedagogia assente na experiência vivida nos territórios indígenas (Smith, 1999; Grande, 2004; Battiste, 2008; Cusicanqui, 2012). Com fundamento em saberes geograficamente enraizados e historicamente situados, procura-se resgatar subjetividades silenciadas, rompendo com formas eurocêntricas de conhecimento (Smith, 2004: 87). Por meio de um diálogo entre pedagogias situadas, Sandy Grande propõe-se iniciar uma conversa 
indígena que possa envolver uma contestação dialógica com teorias críticas e revolucionárias (2004: 3). Os povos indígenas em todo o mundo têm vivido nos seus contextos naturais, adquirindo e desenvolvendo relações sustentáveis com o meio ambiente e transmitindo este conhecimento às gerações seguintes, através de sua língua, cultura e herança. Este conhecimento adquirido incorpora uma grande riqueza de ciências, filosofia, literatura oral, arte e habilidades práticas que têm ajudado a sustentar os povos indígenas e suas terras ao longo de milénios (Battiste, 2008: 497).

Vários são os desafios que se colocam à realização de conversas entre saberes, ou seja, as propostas da ecologia de saberes, da tradução intercultural e interpolítica e das pedagogias pós-abissais elaboradas por Santos (2014: 188-211; 2018: 249-252). Para além da denúncia do eurocentrismo discreto ou explícito, os alertas vão no sentido de identificar, sentir e valorizar a voz dos que participam da resistência ao pensamento abissal, incluindo uma abordagem agregadora da experiência humana, nas suas lutas pelos sentidos autônomos de ser e de saber que devem ser estudados comparativamente. Aprender a (re)aprender, a renovar, a (re)construir os princípios subjacentes a cada cosmovisão, línguas, formas de comunicação está no centro de uma outra proposta pedagógica, plural e dialógica, geradora de um sentido profundo de dignidade humana. Só assim é possível desafiar o imperialismo cognitivo que caracteriza o mundo atual (Santos, 2018).

Unindo lutas, expondo a latência do patriarcado: as mulheres do Sul global

Em diferentes contextos coloniais, a associação perversa entre a autoridade colonial e as autoridades masculinas "locais" (incorporando o corpus de "estruturas de poder tradicionais/indígenas") gerou uma relação íntima entre poder e conhecimento, relação que perdura nos nossos dias, preenchida com o silêncio de exclusões, apagamentos, distorções e ficções arbitrárias sobre as mulheres na história política contemporânea (Cusicanqui, 2012). Várias vozes feministas do Sul global indicam que foi 0 anseio universalista do feminismo eurocêntrico - falar em nome de todas as mulheres, sem refletir sobre suas próprias particularidades e interesses - que o tornou epistemológica e politicamente excludente e suspeito. Oyèrónkẹ́ Oyewùmí (1997) e Maria Lugones (2010), entre outras, têm denunciado as falsas premissas dos discursos universalistas, pois continuam a procurar impor uma visão "universal" cuja origem está no privilégio branco do Norte, em nações e comunidades anteriormente colonizadas, sem declarar suas origens ou interesses no privilégio racial e de classe. 
Ao analisar os vários feminismos como elementos estruturadores (e não subordinados) da colonialidade do poder, ou seja, como categoria colonial, torna-se possível historicizar o patriarcado, salientando as maneiras pelas quais a heteronormatividade, o capitalismo e o colonialismo se encontram imbricados. María Lugones destaca que a imposição de um sistema de gênero binário é constitutiva, tal como a raça, do sistema moderno global de saber e de ser; em alternativa propõe a noção de "sistema de género moderno/colonial" (Lugones, 2010: 370), porque mais ampla que a colonialidade do poder de Quijano.

As lutas pelos direitos das mulheres, pelo reconhecimento do seu direito a ser, vão integrar organicamente os manifestos de muitas lutas nacionalistas anticoloniais (Meneses, 2017). A consciência desta realidade tem levado várias feministas que trabalham nos contextos do Norte a desenvolver instrumentos críticos de análise que permitam abordar os projetos de emancipação tendo a consciência de que muitas das reflexões históricas estão ainda profundamente enraizadas em narrativas, textos e práticas eurocêntricas (Butler, 2004: 129).

Como vários trabalhos produzidos ao longo das últimas décadas sublinham, os feminismos variam amplamente mesmo à escala local e nacional, sendo locais ativos de diálogo interno, negociação e contestação. Refletindo a este propósito, Glória Anzaldúa destacou a necessidade de uma reformulação crítica das categorias a usar para que seja possível dar conta da multiplicidade de problemas e vulnerabilidades que as identidades complexas enfrentam (1987: 77). No contexto africano, Oyéronké Oyewùmí mostra que o colonialismo trouxe consigo a exclusão das mulheres da nova esfera pública colonial (1997: 123). E esta exclusão não é exclusiva a este continente e ao espaço tempo da administração colonial. Esta percepção crítica levou Nelly Richard (2001: 286) a caracterizar o contexto latino-americano como sendo marcado por múltiplos mecanismos de opressão e repressão (colonialismo, imperialismo, militarismo, capitalismo, patriarcado etc.). Pela mesma razão Chandra Mohanty defende que "enquanto a "Mulher/Mulheres" e "Oriente" forem sendo definidos como Outros, ou como periféricos, esse Homem/Humanismo (Ocidental) continua a representar-se a si mesmo como o centro. Não é o centro que determina a periferia, mas sim a periferia que, pela sua delimitação, determina o centro" (1991: 73).

No Sul global, o impacto da relação colonial gerou múltiplas formas locais de opressão que diferem das estruturas de opressão e subordinação teorizadas pelos feminismos do Norte. Neste contexto várias acadêmicas e ativistas têm defendido que a discussão sobre a construção intelectual e política dos "feminismos do Sul global" deve integrar, simultaneamente, dois projetos de luta: a crítica interna dos feminismos que se procuram impor como hegemônicos e, em paralelo, 
a formulação de estratégias feministas emancipatórias, baseadas na autonomia, geografia, história e cultura (Mohanty, Russo e Torres, 1991). Se o primeiro projeto insiste na desconstrução e desaprendizagem em relação ao cânone dominante, o segundo aposta na co-construção e aprendizagem mútua mediante o reconhecimento das diferenças (Mekgwe, 2008: 15). É aqui que se situa, também, a proposta conceptual do "feminismo transnacional" (Swarr e Nagar, 2010) que identifica e situa as diferenças e desigualdades por meio das formações históricas e dos fluxos interculturais e transversais ou mesmo pós-nacionais (globalizantes). Esta proposta, em convergência com a ecologia de saberes e a tradução intercultural e interpolítica, permite gerar pontes entre as várias perspectivas feministas, resgatando a memória das longas histórias de resistência das mulheres aos patriarcados locais e às várias formas de opressão colonial-capitalista.

As trajetórias de lutas dos movimentos de mulheres no Sul global são o espelho de como o feminismo, como teoria e práxis entre lugares vem interromper uma série de oposições binárias, questionado as históricas relações de poder entre o centro e a periferia. Neste contexto dinamizam-se relações de solidariedade que não ofuscam nem paralisam as lutas face às relações de diferença, distância e desigualdade no seio dos diferentes feminismos em luta.

\section{Conclusão: para um mundo pós-abissal}

Este artigo defende uma compreensão diferenciada dos saberes do mundo como simultaneamente diversos e particulares. As Epistemologias do Sul pertencem a esta vasta família de perspectivas que, apesar da sua imensa diversidade, convergem na ideia de que a justiça social global não é possível sem a justiça cognitiva global (Santos, 2014). O espaço de atuação das Epistemologias do Sul, ao insistirem na centralidade das lutas sociais, está muito além do mundo acadêmico.

Para defender a diversidade de saberes que caracteriza o nosso mundo é imprescindível, como sustenta Boaventura de Sousa Santos, construir uma teoria alternativa de alternativas, que dê conta da diversidade e da complexidade das lutas dos subalternizados, cujo saber tem sido ignorado ou descartado. As lutas sustentadas pelas Epistemologias do Sul são aquelas que transformam qualquer possibilidade de liberdade, por menor que seja, em uma oportunidade de libertação, aceitando os riscos envolvidos em tal transformação (Santos, 2018). Uma transformação que almeja alcançar um mundo pós-abissal, que procura ultrapassar os séculos de permanente negação ontológica e injustiça epistêmica.

Contra a evidência mediática e a indústria do entretenimento, vai-se fortalecendo a ideia de um mundo plural, em formas de ser e de saber, anúncio 
inequívoco da presença da diversidade de universos de saber, para além de qualquer tentativa universalista de se (re)constituir como centro. Como sublinha Wa Thiong'o, a localização é importante: "Conhecer-se a si mesmo e ao seu ambiente [é] a base correta para absorver o mundo" (2008: 09). Na coleção de ensaios que integra o volume Movendo o Centro: as lutas por liberdades culturais, este autor apela a que se mova "o centro de sua localização na Europa para um pluralismo de centros, sendo eles próprios locais igualmente legítimos da imaginação humana" (Thiongo, 2008: 08). Estes saberes - e a resistência aos modos de domínio que integram - devem ser encarados como fulcrais ao desenvolvimento da ideia do "universal", porque o mundo é composto de um conjunto tendencialmente infinito de saberes, condição para a descolonização plena do nosso mundo. $\mathrm{O}$ apelo de Thiongo ressoa com o apelo de François Vergès, para quem a preparação de comida é uma forma de pensar o mundo, de forma dialógica. Para Françoise Vergès as zonas de contato entre culturas espelham o que esta autora classifica de uma culinária híbrida, crioula, que renuncia à pureza, e a qualquer tentativa de essencialismo, ao incorporar processos e práticas transétnicas e transculturais.

Desafiando silenciamentos e subalternizações, as literaturas, as artes, têm emprestado, retrabalhado e adaptado os saberes umas das outras, em uma prática de "imitação, apropriação e tradução" (Vergès, 2006: 245). A paisagem que hoje temos desta zona de contatos em saberes autóctones e diaspóricos é de uma riqueza imensa, integrando histórias e saberes sedimentados ao longo de séculos. Estes saberes, espelho de experiências milenares, desafiam as barreiras essencialistas que separam culturas, perpassam o tempo e permeiam a vida de todas as gerações. Delinear percursos de encontros, identificar possíveis zonas de contato acontecem pelo conectar de diferentes formas de sentir e pensar, permitindo que vários saberes, exemplos e conceitos interajam de maneira não hierárquica. É também um convite que nos encontremos neste território, circulando neste, dialogando com quem o integra, como forma de ultrapassar o pensamento abissal. Como Achille Mbembe insiste, no último capítulo do seu livro Crítica da Razão Negra, "existe apenas um mundo [...] composto de uma totalidade de mil peças" (2017: 180), que são os saberes que procurei mapear, e que fornecem os primeiros vislumbres de um futuro descolonizado e mais justo.

\section{Referências}

ALATAS, Syed. The Captive Mind and Creative Development. International Social Science Journal, v. 36, n. 4, pp. 691-699, 1974. 
Ibn Khaldūn and Contemporary Sociology. International Sociology, v. 21, n. 6, pp. 782-795, 2006.

ALPERS, Edward A. The African Diaspora in the Northwestern Indian Ocean: reconsideration of an old problem, new directions for research", Comparative Studies of South Asia, Africa \& the Middle East, v. 17, n. 2, pp. 62-81, 1997.

AMIN, Shahid. The Afterlife of Warrior Saint Ghazi Miyan. Chicago, University of Chicago Press, 2016.

ANZALDÚA, Gloria. Borderlands/La Frontera: The New Mestiza. San Francisco, Aunt Lute Books, 1987.

BATTISTE, Marie. Research Ethics for Protecting Indigenous Knowledge and Heritage: Institutional and researcher responsibilities. In: Denzin, Norman K.; Lincoln, YVONNA S.; Smith, Linda T. (ed.), Handbook of Critical and Indigenous Methodologies. Berkeley, Sage, pp. 497-509, 2008.

BHABHA, Homi K. The Location of Culture. Abingdon, Routledge, 2004.

BLAUNER, Robert. Racial Oppression in America. New York, Harper \& Row, 1972.

BOUTELDJA, Houria e KHIARI, Sadri. Nous sommes les Indigènes de la République. Paris, Éditions Amsterdam, 2012.

BUCK-MORSS, Susan. Hegel, Haiti, and Universal History. Pittsburgh, PA, University of Pittsburgh Press, 2009.

BUTLER, Judith. Undoing Gender. New York, Routledge, 2004.

CALDERÓN-ZAKS, Michael. Domestic Colonialism: The overlooked significance of Robert L. Allen's contributions. The Black Scholar, v. 40, n. 2, pp. 39-48, 2010.

CASANOVA, Pablo Gonzalez. Internal Colonialism and National Development. Studies in Comparative International Development, v. 1, n. 4, pp. 27-37, 1965.

CHAKRABARTY, Dipesh. Subaltern Studies and Postcolonial Historiography. In: DELANTY, Gerard e ISIN, Engin F. (ed.), Handbook of Historical Sociology. London, Sage, pp. 191-204, 2003.

CHAMBERS, Ian. Mediterranean Crossings: The politics of an interrupted modernity. Durham, NC, Duke University Press, 2008.

CLIFFORD, James. Diasporas. Cultural Anthropology, v. 9, n. 3, pp. 302-338, 1994.

CONNELL, Raewyn. Southern Theory: The Global Dynamics of Knowledge in Social Science. Cambridge, Polity Press, 2007.

COULTHARD, Glen. Red Skin, White Masks: Rejecting the colonial politics of recognition. Minneapolis, University of Minnesota Press, 2014.

CUSICANQUI, Silvia Rivera. Ch'ixinakax utxiwa: A reflection on the practices and discourses of decolonization. South Atlantic Quarterly, v. 111, n. 1, pp. 95-109, 2012.

DAVIS, Angela. Public Imprisonment and Private Violence: Reflections on the hidden punishment of women. In: HOLMSTROM, Nancy (ed.), The Socialist project: 
A contemporary reader in theory and politics. New York, Monthly Review Press, pp. 239-249.

Freedom Is a Constant Struggle: Ferguson, Palestine, and the foundations of a movement. Chicago, Haymarket Books, 2015.

DELEUZE, Gilles. Difference and Repetition. New York, Columbia University Press, 1994.

DIAGNE, Souleymane Bachir. On the Postcolonial and the Universal? Rue Descartes, v. 78 , n. 2, pp. 07-18, 2013.

. Négritude. In: ZALTA, Edward N. (ed.). The Stanford Encyclopedia of Philosophy (Summer 2018 Edition). 2018. Disponível em: <https://plato.stanford.edu/ archives/sum2018/entries/negritude/>. Acesso em: 26 jan. 2020.

DU BOIS, W. E. B. The Souls of Black Folk. New York, Dover Publications, 1903.

DUSSEL, Enrique D. Eurocentrism and Modernity. Boundary 2, v. 20, n. 3, pp. 65-76, 1993. World-System and 'Trans' Modernity. Nepantla. Views from the South, v. 2, n. 3 , pp. 221-245, 2002.

EDELMAN, Marian Wright. Losing Our Children in America's Cradle to Prison Pipeline. In: National Urban League. The State of Black America 2007: Portrait of the Black Male. New York, National Urban League, pp. 219-227, 2007.

ELKINS, Caroline e PEDERSEN, Susan. Introduction - Settler Colonialism: A Concept and Its Uses. In: ELKINS, Caroline e PEDERSEN, Susan (ed.). Settler Colonialism in the Twentieth Century: Projects, Practices, Legacies. London, Routledge, pp. 01-23, 2005.

FABIAN, Johannes. Time and the Other: How Anthropology Makes Its Object. New York, Columbia University Press, 2014.

FALS BORDA, Orlando. Ciencia Propia y Colonialismo Intelectual. México, Editorial Nuestro Tiempo, 1970.

FANON, Frantz. Peau noire, masques blancs. Paris, Seuil, 1952.

. Les damnés de la Terre. Paris, Maspero, 1961.

FREIRE, Paulo. Pedagogy of the Oppressed. New York, Continuum, 1970.

GANDHI, Mahatma. The Gandhi Reader. Bloomington, IN, Indiana University Press, 1956. GELLNER, Ernest. Nationalism. London, Phoenix, 1995.

GILLEY, Bruce. The Case for Colonialism. Third World Quarterly, o (o) (article withdrawn by the author), 2017.

GIMENO, Juan Carlos e CASTAÑO, Ángeles. Antropología y Epistemologías del Sur: el reto de la descolonización de la produción del conocimiento. Revista Andaluza de Antropología, v. 10, pp. 01-09, 2016.

GLISSANT, Édouard. Caribbean Discourse: Selected Essays. Charlottesville, University of Virginia Press, 1989.

. Poetics of Relation. Ann Arbor, University of Michigan Press, 1997. 
GORDON, Jane A. Creolizing Political Theory: Reading Rousseau through Fanon. New

York, Fordham University Press, 2014.

GORDON, Lewis. Existentia Africana: Understanding Africana Existential Thought.

New York, Routledge, 2000.

What Fanon Said: A Philosophical Introduction to His Life and Thought. New

York, Fordham University Press, 2015.

GRANDE, Sandy. Red Pedagogy: Native American social and political thought. Lanham, MD, Rowman \& Littlefield, 2004.

GROSFOGUEL, Ramón. What is Racism. Journal of World-Systems Research, v. 22, n. 1, pp. 09-15, 2016.

GUHA, Ranajit. On Some Aspect of the Historiography of Colonial India. In: GUHA, Ranajit (ed.), Subaltern Studies I: Writings on South Asian History and Society. New Delhi, Oxford University Press, pp. 01-08, 1982.

Elementary Aspects of Peasant Insurgency in Colonial India. Durham, N.C., Duke University Press, 1999.

GUTIÉRREZ, Ramón A. Internal Colonialism. An American theory of race. Du Bois Review, v. 1, n. 2, pp. 281-295, 2004.

HARRIS, Andrea. The Subprime Wipeout: Unsustainable loans erase gains made by African American women. In: National Urban League. The State of Black America 2008: the Black Woman's Voice. New York, National Urban League, pp. 125-133, 2008. HOUNTONDJI, Paulin. Introduction: Recentring Africa. In: HOUNTONDJI, Paulin (ed.). Endogenous Knowledge: Research trails. Dakar, CODESRIA, pp. 01-39, 1997. . Knowledge of Africa, Knowledge by Africans: Two perspectives on African studies. RCCS Annual Review, v. 1, pp. 01-11, 2009.

KALDOR, Mary. Cosmopolitanism versus Nationalism: the New Divide? In: CAPLAN, Richard e FEFFER, John (eds.). Europe's New Nationalism: States and Minorities in Conflict. Oxford, Oxford University Press, pp. 42-58, 1996.

KHIARI, Sadri. Pour une politique de la racaille, Immigré-e-s, indigènes et jeunes banlieues. Paris, Éditions Textuel, 2006.

LUGONES, María. The Coloniality of Gender. In: MIGNOLO, Walter e ESCOBAR, Arturo (ed.). Globalization and the Decolonial Option. London, Routledge, pp. 369-390, 2010. MALDONADO-TORRES, Nelson. On the Coloniality of Being. Cultural Studies, v. 21, n. 2-3, pp. 240-270, 2007.

A Topologia do Ser e a Geopolítica do Conhecimento: Modernidade, império e colonialidade. In: SANTOS, Boaventura de Sousa e MENESES, Maria Paula (ed.). Epistemologias do Sul. Coimbra, CES-Almedina, pp. 337-382, 2009.

MARIÁTEGUI, José Carlos. Siete Ensayos de Interpretación de la Realidad Peruana. Barcelona, Lingkua, 2009 [1928]. 
MBEMBE, Achille. Provisional Notes on the Postcolony. Africa, v. 62, n. 1, pp. 03-37, 1992. Necropolitics. Public Culture, v. 15, n. 1, pp. 11-40, 2003. . Critique of Black Reason. Durham, NC., Duke University Press, 2017.

MEKGWE, Pinkie. Theorizing African Feminism(s): The 'colonial' question. Quest: An African Journal of Philosophy, v. XX, pp. 11-22, 2008.

MENESES, Maria Paula. O 'indígena' africano e o colono 'europeu': a construção da diferença por processos legais. E-cadernos CES [Online], v. 7, pp. 68-93, 2010. Disponível em: <http://journals.openedition.org/eces/403>. Acesso em: 26 jan. 2021.

. Os Sentidos da Descolonização: Uma análise a partir de Moçambique. OPSIS, v. 16, n. 1, pp. 26-44, 2016.

De Bandung à Luta Armada: A construção de alianças na África Austral. In: ARAÚJO, Caio S. (ed.). A Luta Continua, 40 Anos Depois: Histórias entrelaçadas na África Austral. Maputo, Alcance, pp. 59-78, 2017.

. Colonialismo como violência: a 'missão civilizadora' de Portugal em Moçambique. Revista Crítica de Ciências Sociais, Número especial | 2018, 115-140, URL: http:// journals.openedition.org/rccs/7741; DOI: https://doi.org/10.400o/rccs.7741

MIGNOLO, Walter. Geopolitics of Sensing and Knowing: On (de)coloniality, border thinking, and epistemic disobedience. Confero. Essays on Education Philosophy and Politics, v. 1, n. 1, pp. 129-150, 2013.

MOHANTY, Chandra T. Under Western Eyes: feminist scholarship and colonial discourses. In: MOHANTY, Chandra T. e RUSSO, Ann e TORRES, Lourdes (ed.). Third World Women and the Politics of Feminism. Bloomington, IN, Indiana University Press, pp. 51-80, 1991.

MOHANTY, Chandra Talpade; RUSSO, Ann e TORRES, Lourdes (ed.). Third World Women and the Politics of Feminism. Bloomington, IN, Indiana University Press, 1991. NKRUMAH, Kwame. Neo-colonialism: The last stage of imperialism. London, Thomas Nelson \& Sons, 1965 .

OYEWÙMÍ, Oyèrónké. The Invention of Women. Making an African sense of western gender discourses. Minneapolis, University of Minnesota Press, 1997.

PATEL, Sujata. Gazing Backward or Looking Forward: Colonial modernity and the making of a sociology of modern India. In: ARJOMAND, Said A. (ed.). Social Theory and Regional Studies in the Global Age. Albany, NY, SUNY Press, pp. 437-46o, 2014.

QUIJANO, Aníbal. Colonialidad y Modernidad/Racionalidad. Perú Indígena, v. 29, pp. 11-20, 1991.

Colonialidade do Poder, Eurocentrismo e América Latina. Buenos Aires, CLACSO, 2005.

RICHARD, Nelly. Feminism and Postmodernism. In: MENDIETA, Eduardo e LANGECHURIÓN, Pedro (ed.). Latin America and Postmodernity. New York, Humanity Books, pp. 275-290, 2001. 
ROBINE, Jérémy. Les 'Indigènes de la République': nation et question postcoloniale. Territoires des enfants de l'immigration et rivalité de pouvoir. Hérodote, v. 120, pp. 118-148, 2006.

SAID, Edward. Foreword. In: GUHA, Ranajit e SPIVAK, Gayatri C. (ed.). Selected Subaltern Studies. New York, Oxford University Press, v-x, 1988.

SANTOS, Boaventura de Souza. Um discurso sobre as Ciências. São Paulo: Cortez, $4^{\mathrm{a}}$ Edição, 2006.

. Beyond Abyssal Thinking: from global lines to ecologies of knowledges. Review, v. XXX, n. 1, pp. 45-89, 2007.

. Epistemologies of the South. Justice against epistemicide. New York, Routledge, 2014. The Resilience of Abyssal Exclusions in Our Societies: Toward a post-abyssal law. Tilburg Law Review, v. 22, pp. 237-258, 2017.

The End of the Cognitive Empire: the coming of age of Epistemologies of the South. Durham, NC, Duke University Press, 2018.

SENGHOR, Léopold. Nation et voie africaine du socialisme (Liberté, tome 2) Paris, Seuil, 1971. SHARIATI, Ali. On the Sociology of Islam. Berkeley, Mizan, 1979.

SMITH, Linda Tuhiwai. Decolonizing Methodologies. Research and indigenous peoples. London, Zed Books, 1999.

. On Tricky Ground: Researching the Native in the age of uncertainty. In: DENZIN, Norman K. e LINCOLN, Yvonna S. (ed.). The SAGE Handbook of Qualitative Research. Thousand Oaks, CA, Sage, pp. 85-108, 2004.

SOUTH African Communist Party. The Road to South African Freedom. London, Inkululeko Publications, 1962.

STAVENHAGEN, Rodolfo. Class, Colonialism, and Acculturation. In: HOROWITZ, Irving L. (ed.). Masses in Latin America. New York, Oxford University Press, pp. 235-288, 1970.

SUKARNO. Address given by Sukarno at the opening of the Bandung conference, 18 April 1955. In: Asia-Africa speak from Bandung. Djakarta, Ministry of Foreign Affairs, Republic of Indonesia, pp. 19-29, 1955.

SWARR, Amanda e NAGAR, Richa (ed.). Critical Transnational Feminist Praxis. Albany, NY, SUNY Press, 2010.

TABB, William K. The Political Economy of the Black Ghetto. New York, W. W. Norton, 1970.

TABAR, Linda e DESAI, Chandni. Decolonization is a Global Project: From Palestine to the Americas. Decolonization: Indigeneity, Education \& Society, v. 6, n. 1, pp. i-xix, 2017. THIONG'O, Ngugi wa. Decolonizing the Mind. The struggle for cultural freedoms. London, James Currey, 1993. Moving the Centre: The Struggle for Cultural Freedoms. Rochester, NY, James Currey, 2008. 
Something Torn and New: An African renaissance. New York, Basic Civitas Books, 2009.

TROUILLOT, Michel-Rolph. The Otherwise Modern. Caribbean Lessons from the Savage Slot. In: KNAUFT, Bruce M. (ed.). Critically Modern: alternatives, alterities, anthropologies. Bloomington, Indiana University Press, pp. 220-237, 2002.

TUCK, Eve e YANG, K. Wayne. Decolonization is Not a Metaphor. Decolonization: Indigeneity, Education \& Society, v. 1, n. 1, pp. 01-40, 2012.

VALDEZ, Luis e RUBALCAVA, Roberto. Venceremos! Mexican American statement on travel to Cuba. In: VALDEZ, Luis e STEINER, Stan (ed.). Aztlán: An anthology of Mexican American literature. New York, Alfred A. Knopf, pp. 215-218, 1972.

VERGÈS, Françoise. Let's Cook. In: NUTTALL, Sarah (ed.). Beautiful/Ugly: Diaspora Aesthetics. Durham, NC, Duke University Press, pp. 241-256, 2006.

WALSH, Catherine. Interculturalidad, Estado, Sociedad: Luchas (de) coloniales de nuestra época. Quito, Ediciones Abya-Yala, 2009.

WILDER, Gary. Freedom Time: Negritude, decolonization, and the future of the world. Durham, NC, Duke University Press, 2015.

WIREDU, Kwasi. Toward Decolonizing African Philosophy and Religion. African Studies Quarterly, v. 1, n. 4, pp. 17-46, 1998.

WOLFE, Peter. Settler Colonialism and the Elimination of the Native. Journal of Genocide Research, v. 8, n. 4, pp. 387-409, 2006.

WYNTER, Sylvia. Unsettling the Coloniality of Being/Power/Truth/Freedom: Towards the human, after man, its overrepresentation-an argument. CR: The New Centennial Review, v. 3, n. 3, pp. 257-337, 2003.

Recebido em: 02/12/2020

Aprovado em: 21/12/2020

\section{Como citar este artigo:}

MENESES, Maria Paula. Desafios à descolonização epistémica: práticas, contextos e lutas para além das fraturas abissais. Contemporânea - Revista de Sociologia da UFSCar, v. 10, n. 3, set.- dez. 2020, pp. 1067-1097. 